\title{
Pengaruh Proses Fermentasi pada Daun Centella asiatica oleh Acetobacter tropicalis Terhadap Aktivitas Trombolitik
}

\author{
Lailatul Nuraini, Bambang Tri Purwanto, Achmad Syahrani, Riesta Primaharinastiti, Achmad Toto \\ Poernomo*
}

Departemen Ilmu Kefarmasian, Fakultas Farmasi, Universitas Airlangga, Jawa Timur, Indonesia

*E-mail: achmad-t-p@ff.unair.ac.id

(Submit 19/12/2021, Revisi 20/12/2021, Diterima 30/12/2021, Terbit 31/12/2021)

\begin{abstract}
Abstrak
Agen trombolitik merupakan plasminogen activator yang dapat memecah fibrin menjadi fibrin degradation product (FDP) dan dapat digunakan pada terapi penyakit kardiovaskular. Agen trombolitik dapat diperoleh dari mikroorganisme seperti Acetobacter tropicalis InaCC B374 dan dari tanaman seperti Centella asiatica. Kedua sumber agen trombolitik tersebut dapat dilakukan kombinasi melalui proses fermentasi untuk meningkatkan efek terapetiknya. Proses fermentasi sendiri dipengaruhi oleh beberapa faktor termasuk media fermentasi dan waktu fermentasi. Penelitian ini bertujuan untuk mengetahui pengaruh proses fermentasi terhadap peningkatan aktivitas trombolitik dari hasil fermentasi Centella asiatica oleh Acetobacter tropicalis InaCC B374 pada berbagai variasi waktu fermentasi. Preparasi dilakukan dengan memfermentasi Centella asiatica selama 24,48 , dan 72 jam pada suhu $30^{\circ} \pm 1^{\circ} \mathrm{C}$ dengan kecepatan pengocokan $100 \mathrm{rpm}$ kemudian ditentukan aktivitas trombolitiknya dengan metode clot lysis yang dilakukan inkubasi pada suhu $37^{\circ} \pm 1^{\circ} \mathrm{C}$ selama 60 menit. Hasil pengujian aktivitas trombolitik menunjukkan bahwa terjadi peningkatan aktivitas trombolitik setelah dilakukan proses fermentasi selama 24, 48 dan 72 jam dan aktivitas trombolitik maksimum tercapai pada hasil fermentasi 72 jam. Centella asiatica yang difermentasi selama 72 jam menunjukkan nilai indeks trombolitik yang paling besar $(82,03)$ jika dibandingkan dengan infusa Centella asiatica tanpa fermentasi $(37,39)$ dan Acetobacter tropicalis InaCC B374 $(37,68)$. Disimpulkan bahwa proses fermentasi Centella asiatica oleh Acetobacter tropicalis InaCC B374 secara signifikan dapat meningkatkan aktivitas trombolitik keduanya.
\end{abstract}

Kata kunci: Acetobacter tropicalis, aktivitas trombolitik, Centella asiatica, clot lysis, fermentasi

\section{Pendahuluan}

Agen trombolitik merupakan suatu plasminogen aktivator yang dapat mengubah proenzim plasminogen menjadi enzim aktif plasmin untuk mendegradasi fibrin, suatu komponen utama pada bekuan darah yang terbentuk melalui proses proteolisis oleh trombin ${ }^{(1,2)}$. Selain sebagai plasminogen activator, agen trombolitik juga dapat berupa 
enzim fibrinolitik yang secara langsung mendegradasi fibrin ${ }^{(3)}$. Pada kondisi normal tubuh manusia, bekuan fibrin akan dihidrolisis oleh plasmin menjadi fibrin degradation product (FDP), namun apabila terjadi ketidakseimbangan pada sistem hemostasis menyebabkan proses hidrolisis ini tidak terjadi sehingga memicu terbentuknya trombus yang akan menyumbat aliran darah. Pada kondisi tersebut dapat diatasi dengan pemberian sediaan enzim fibrinolitik seperti urokinase, streptokinase dan t-PA (tissue plasminogen activator) ${ }^{(4)}$. Saat ini penggunaan klinis sediaan enzim fibrinolitik tersebut dinilai kurang efektif karena memiliki keterbatasan diantara lain spesifisitas fibrin yang rendah, waktu paruh kerja yang pendek dan dapat menimbulkan efek samping yang tidak diinginkan seperti perdarahan pada gastrointestinal dan timbulnya reaksi alergi. Oleh karena itu, hingga saat ini sudah mulai dikembangkan agen trombolitik dari sumber mikroorganisme dan tanaman yang lebih aman dan lebih efektif(5,6).

Mikroorganisme utamanya bakteri merupakan penghasil enzim fibrinolitik yang paling potensial(7). Salah satu bakteri yang telah dikarakterisasi aktivitas fibrinolitiknya yaitu Acetobacter tropicalis. Acetobacter tropicalis pada fase pertumbuhannya dapat menghasilkan protease sehingga dapat dipertimbangkan sebagai sumber enzim fibrinolitik yang merupakan bagian dari protease ${ }^{(8)}$. Bakteri lain penghasil agen trombolitik juga cukup banyak diantaranya Staphylococcus sp. AJ, Bacillus subtilis BK17, Bacillus natto NRRL 3666, dan Pseudomonas sp. TKU015(4,9). Pengembangan agen trombolitik dari sumber bakteri banyak mendapat perhatian karena keragaman biokimia dan fisiologis bakteri dapat meningkatkan spesifisitas target dari protease fibrinolitik. Penggunaan bakteri juga menguntungkan karena mudah dikembangbiakkan dan dapat diperoleh dalam waktu yang lebih singkat dibandingkan sumber agen trombolitik lainnya ${ }^{(10)}$.

Selain dari sumber bakteri, potensi agen trombolitik juga dapat diperoleh dari tanaman salah satunya yaitu Centella asiatica atau dikenal dengan nama lokal pegagan. Centella asiatica memiliki kandungan senyawa bioaktif seperti asam madekasat, asam asiatat, madekasosida dan asiatikosida yang berperan penting dalam aktivitas farmakologinya ${ }^{(11)}$. Centella asiatica telah dilaporkan memiliki aktivitas trombolitik yang cukup besar karena memiliki kemampuan dalam melisiskan trombus sebagai analog tissue plasminogen activator (t-PA)(12). Selain itu, adanya kandungan flavonoid pada Centella asiatica dapat meningkatkan fungsi sel endotel pembuluh darah untuk meningkatkan pelepasan agen trombolitik ${ }^{(13)}$. Tanaman lain penghasil agen trombolitik juga cukup beragam diantaranya Allium sativum L., Ananas comosus (L.) Merr., Lycopersicum esculentum Mill., dan Curcuma longa L. (14).

Berdasarkan kedua sumber agen trombolitik tersebut, saat ini sudah mulai dilakukan penelitian mengenai kombinasi tanaman dan bakteri sebagai penghasil agen trombolitik yang potensial melalui proses fermentasi. Adanya proses fermentasi dapat meningkatkan efek terapetik yang disebabkan oleh adanya proses biotransformasi senyawa pada tanaman untuk menghasilkan produk bioaktif baru(15). Pada saat proses fermentasi juga terjadi biosintesis enzim proteolitik dalam hal ini termasuk protease fibrinolitik. Proses fermentasi dipengaruhi oleh beberapa faktor diantaranya media fermentasi, suhu, pH dan waktu fermentasi. Untuk mendapatkan metabolit yang maksimal maka dalam proses fermentasi dibutuhkan media yang sesuai bagi pertumbuhan bakteri(16). 
Pemilihan Centella asiatica sebagai media fermentasi karena Centella asiatica dilaporkan memiliki kandungan protein $21,9 \%$; lipid $6,0 \%$; karbohidrat $42,9 \%$; vitamin dan garam mineral seperti kalsium, magnesium, besi dan zink $^{(17)}$. Kandungan nutrisi yang cukup besar pada daun Centella asiatica dapat digunakan sebagai sumber nitrogen dan karbon yang baik bagi pertumbuhan Acetobacter tropicalis dan dapat digunakan sebagai bahan dasar dalam proses produksi enzim ${ }^{(18,19)}$. Fermentasi Centella asiatica untuk menghasilkan agen trombolitik belum pernah dilaporkan pada penelitian lain. Untuk mengetahui aktivitas trombolitik pada penelitian ini digunakan metode clot lysis dengan melakukan pengamatan trombus yang terlisiskan setelah pemberian agen trombolitik ${ }^{(20)}$. Diharapkan setelah dilakukan proses fermentasi akan terjadi peningkatan aktivitas trombolitik sehingga penelitian ini dapat menjadi peluang dalam penemuan sumber agen trombolitik baru dari hasil fermentasi tanaman oleh bakteri.

\section{Metode}

\section{Alat}

Alat yang digunakan dalam penelitian ini meliputi cawan petri (Pyrex $\left.{ }^{\circledR}\right)$, gelas kimia $\left(\right.$ Pyrex $^{\circledR}$ ), gelas ukur (Pyrex ${ }^{\circledR}$ ), Erlenmeyer (Pyrex ${ }^{\circledR}$ ), ayakan mesh 500, autoclave HL-340 Series Vertical Type Steam Sterilizer, vortex maxi mixII IKA ${ }^{\circledast}$, centrifuge Hettich Zentrifugen EBA 20, mikropipet Eppendorf ${ }^{\circledR}$ research plus, inkubator Memmert IN110 genius 3, timbangan digital Sartorius Type BP 2215 ${ }^{\circledR}$.

\section{Bahan}

Bahan-bahan yang digunakan dalam penelitian ini meliputi bakteri uji Acetobacter tropicalis InaCC B374 yang merupakan koleksi Pusat Penelitian Biologi, Lembaga IImu Pengetahuan Indonesia (LIPI), Simplisia kering daun Centella asiatica koleksi dari Center for Research and Development of Medicinal Plants and Traditional Medicine Tawang Mangu Indonesia, darah segar yang diambil melalui Vena Jugularis sapi di tempat pemotongan Surya Pegirikan slaughterhouse, bahan untuk pemeliharaan bakteri yaitu glucose yeast peptone agar ${ }^{\circledR}$ (Merck), bahan untuk media pertumbuhan bakteri yaitu glucose yeast peptone broth ${ }^{\circledR}$ (Merck), skimed milk agar (Merck) untuk bahan media pengujian proteolitik, fibrin bovine blood Simagchem ${ }^{\circledR}$ untuk bahan media fibrin plate pada pengujian fibrinolitik, aquadest, agarosa, methylene blue (Merck), dapar fosfat (K2HPO4 dan KH2PO4), dan fibrinase (Dipa Pharmalab Intersains).

\section{Prosedur}

1. Preparasi Media dan Pemeliharaan Bakteri

Acetobacter tropicalis InaCC B374 diremajakan pada media Glucose Yeast Peptone (GYP) agar miring yang dibuat dengan melarutkan 2 gram glukosa; 0,5 gram yeast; 0,5 gram pepton dan 1,5 gram agar dalam $100 \mathrm{~mL}$ aquadest. 
Campuran media kemudian dimasukkan ke dalam tabung reaksi masing-masing sebanyak $10 \mathrm{~mL}$ dan disterilkan dengan autoklaf pada suhu $121^{\circ} \mathrm{C}$ selama 15 menit. Selanjutnya digesekkan satu Öse biakan bakteri murni ke dalam media GYP agar miring dan diinkubasi selama 24 jam pada suhu $37^{\circ} \pm 1^{\circ} \mathrm{C}$.

\section{Preparasi Inokulum Glucose Yeast Peptone Broth}

Terlebih dahulu membuat media GYP broth dengan melarutkan 3 gram glukosa; 1 gram yeast dan 1 gram pepton dalam $200 \mathrm{~mL}$ aquadest kemudian disterilisasi menggunakan autoklaf pada suhu $121^{\circ} \mathrm{C}$ selama 15 menit. Selanjutnya dilakukan pembuatan suspensi bakteri dengan cara menambahkan $10 \mathrm{~mL}$ GYP broth steril ke dalam inokulum Acetobacter tropicalis yang telah diinkubasi selama 24 jam, divortex hingga terbentuk suspensi ( \pm 15 menit). Suspensi bakteri diukur dengan spektrofotometer sampai diperoleh transmitan $25 \%$ pada panjang gelombang 580 $\mathrm{nm}$. Sebanyak $10 \mathrm{~mL}$ suspensi bakteri dipindahkan kedalam Erlenmeyer yang berisi media GYP broth ( $40 \mathrm{~mL}$ ) kemudian diinkubasi dengan shaker incubator pada suhu $30^{\circ} \pm 1^{\circ} \mathrm{C}$ dengan kecepatan pengocokan $100 \mathrm{rpm}$ selama 24 jam $^{(21)}$.

3. Pembuatan Infusa Daun

Simplisia kering daun Centella asiatica diblender hingga halus untuk mengecilkan ukuran partikelnya dan diayak dengan menggunakan ayakan mesh 500 . Sejumlah 40 gram serbuk daun Centella asiatica selanjutnya diseduh dengan $800 \mathrm{ml}$ aquadest suhu $50^{\circ} \mathrm{C}$ dan didiamkan selama 45 menit, kemudian supernatan yang diperoleh disaring dengan menggunakan saringan lalu disterilkan dengan autoklaf pada suhu $121^{\circ} \mathrm{C}$ selama 15 menit (modifikasi metode Madhusudhan, Neeraja, and Devi, 2014) $(22,23)$.

\section{Proses Produksi dan Kondisi Fermentasi}

Fermentasi dilakukan dalam dua belas erlenmeyer yang masing-masing berisi $50 \mathrm{ml}$ infusa Centella asiatica. Kemudian ditambahkan $10 \mathrm{~mL}$ inokulum starter Acetobacter tropicalis InaCC B374 pada masing-masing erlenmeyer. Selanjutnya dilakukan proses fermentasi pada suhu $30^{\circ} \pm 1^{\circ} \mathrm{C}$ dengan kecepatan pengocokan $100 \mathrm{rpm}$ selama 0, 24, 48 dan 72 jam $^{(24)}$.

\section{Uji Aktivitas Proteolitik (Skimed Milk Agar)}

Media skim milk agar (SMA) dibuat dengan mencampurkan 3\% susu skim dan 3\% agar dalam aquadest $100 \mathrm{~mL}$. Campuran media selanjutnya dipasteurisasi pada suhu $80^{\circ} \mathrm{C}$ selama 3 menit dan dipindahkan pada cawan petri steril masing-masing sebanyak $20 \mathrm{~mL}$. Media SMA didiamkan pada suhu ruang dan dibiarkan memadat. Pada media SMA dibuat sumuran dengan diameter $\pm 7,00 \mathrm{~mm}$ menggunakan logam pelubang steril kemudian diinokulasikan inokulum starter Acetobacter tropicalis InaCC B374, infusa Centella asiatica, hasil fermentasi Centella asiatica (jam ke 0, 24, 48, dan 72), nattokinase (kontrol positif) dan dapar fosfat $\mathrm{pH} 7$ (kontrol negatif) 
masing-masing sebanyak $15 \mu \mathrm{l}$. Kemudian cawan petri diinkubasi pada suhu $37^{\circ} \pm 1^{\circ} \mathrm{C}$ selama 18 jam. Zona jernih yang terbentuk disekitar sumuran diukur diameternya menggunakan jangka sorong. Zona jernih tersebut menunjukkan adanya aktivitas proteolitik pada sampel (modifikasi metode Poernomo, Isnaeni and Purwanto, 2014)(25).

\section{Uji Aktivitas Enzim Fibrinolitik (Fibrin plate)}

Media fibrin plate dibuat dengan mencampurkan $1 \%$ fibrin dan $2 \%$ agarosa dalam $100 \mathrm{~mL}$ larutan dapar fosfat dengan $\mathrm{pH} 7$ kemudian dilakukan pasteurisasi pada suhu $80^{\circ} \mathrm{C}$ selama 3 menit. Dalam keadaan masih panas, campuran media dituang sebanyak $20 \mathrm{~mL}$ pada cawan petri steril. Kemudian ditambahkan metilen biru 1000 $\mu \mathrm{L}$ untuk mempermudah pengamatan zona jernih yang terbentuk pada fibrin plate dan didiamkan pada suhu ruang selama 30 menit hingga memadat. Pada media fibrin plate dibuat sumuran dengan diameter $\pm 7,00 \mathrm{~mm}$ kemudian diinokulasikan inokulum starter Acetobacter tropicalis InaCC B374, infusa Centella asiatica, hasil fermentasi Centella asiatica (jam ke 0, 24, 48, dan 72), nattokinase (kontrol positif) dan dapar fosfat $\mathrm{pH} 7$ (kontrol negatif) masing-masing sebanyak $15 \mu \mathrm{l}$ kemudian diinkubasi pada suhu $37^{\circ} \pm 1^{\circ} \mathrm{C}$ selama 18 jam dan zona jernih dapat diukur dengan menggunakan jangka sorong. Adanya zona jernih merupakan indikasi adanya degradasi fibrin (modifikasi metode Ashipala and $\mathrm{He}, 2008)^{(26)}$.

\section{Uji Aktivitas Trombolitik dengan Metode Clot lysis}

Darah segar yang diambil melalui Vena Jugularis sapi di tempat pemotongan sapi Surya Pegirikan slaughterhouse segera dimasukkan ke dalam tabung darah lalu dimasukkan termos yang berisi ice gel pack untuk mempertahankan suhu $2^{\circ}-6^{\circ} \mathrm{C}$ agar tidak terjadi penggumpalan darah. Sejumlah $500 \mu \mathrm{l}$ darah dipindahkan pada tabung mikrosentrifus yang telah ditimbang sebelumnya kemudian darah diinkubasi pada suhu $37^{\circ} \pm 1^{\circ} \mathrm{C}$ selama 45 menit. Setelah darah menggumpal, tabung mikrosentrifus disentrifugasi dengan kecepatan 3000 rpm selama 5 menit kemudian serum dihilangkan dengan cara didekantasi dan tabung ditimbang kembali untuk menentukan berat gumpalan darah. Pada masing-masing tabung mikrosentrifus yang berisi gumpalan darah diinokulasikan inokulum starter Acetobacter tropicalis InaCC B374, infusa Centella asiatica, hasil fermentasi Centella asiatica (jam ke 0, 24, 48, dan 72), nattokinase (kontrol positif) dan dapar fosfat $\mathrm{pH} 7$ (kontrol negatif) masingmasing sebanyak $500 \mu \mathrm{l}$ kemudian diinkubasi pada suhu $37^{\circ} \pm 1^{\circ} \mathrm{C}$ selama 60 menit. Selanjutnya tabung mikrosentrifus disentrifugasi dengan kecepatan 3000 rpm selama 5 menit. Sisa cairan lisis pada tabung dibuang dengan cara didekantasi kemudian tabung ditimbang kembali sebagai berat setelah lisis ${ }^{(27,28)}$.

Rumus perhitungan clot lysis :

$\%$ clot lysis $=(($ berat gumpalan darah awal-berat gumpalan darah setelah lisis $) /$ berat gumpalan darah awal) $\times 100$ 


\section{Analisis Statistik}

Data rata-rata 3 pengulangan dan 3 paralel untuk setiap pengulangan. Nilai rata-rata dan standar deviasi dihitung menggunakan perangkat lunak Microsoft Excel (Office 2013, Microsoft). Nilai rata-rata dibandingkan dengan menggunakan software statistik SPSS (SPSS versi 22.0, SPSS Inc., Chicago, IL, USA). Selanjutnya dilakukan uji lanjut LSD dan Duncan pada taraf kebermaknaan 0,05 untuk melihat perbedaan yang bermakna pada aktivitas trombolitik dan variasi waktu fermentasi.

\section{Hasil dan Pembahasan}

Pertama dilakukan pengujian aktivitas proteolitik pada media SMA sebagai identifikasi untuk membuktikan bahwa sampel uji menghasilkan enzim proteolitik. Adanya enzim proteolitik dapat memecah protein kasein pada media SMA yang terdiri dari ikatan antara fosfoprotein dengan kalsium membentuk kalsium kalseinat yang tidak larut dalam air dan membentuk koloid. Pemecahan protein kasein oleh enzim proteolitik akan menghasilkan peptida dan asam amino yang larut dalam air sehingga teramati sebagai zona jernih seperti yang terlihat pada Gambar $\mathbf{1}^{(25)}$.

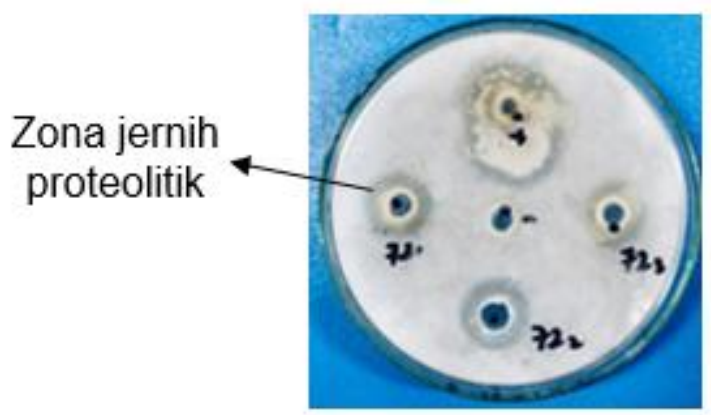

Gambar 1 Contoh hasil pengamatan zona jernih aktivitas proteolitik pada hasil fermentasi Centella asiatica selama 72 jam (Keterangan: $72_{123}=$ hasil fermentasi selama 72 jam replikasi $1,2,3 ;+=$ kontrol positif; - = kontrol negatif).

Pada penelitian ini keseluruhan sampel uji terbukti menghasilkan zona jernih disekitar sumuran, hal tersebut merupakan indikasi dihasilkannya enzim proteolitik oleh sampel uji. Setelah dilakukan pengukuran zona jernih, hasil pengujian aktivitas proteolitik kemudian dinyatakan dalam indeks proteolitik yang merupakan perbandingan antara diameter zona jernih sampel uji dengan diameter sumuran.

Berdasarkan Tabel 1 dibawah diperoleh hasil pengukuran diameter zona jernih pada masing-masing sampel uji. Hasil indeks proteolitik inokulum starter Acetobacter tropicalis InaCC B374 memiliki nilai yang paling mendekati standar nattokinase dengan rasio sebesar $96,42 \%$ atau 0,96 kali lebih kecil dibanding nattokinase dengan nilai indeks proteolitik 2,96. Pada uji proteolitik sampel uji lainnya juga menghasilkan zona jernih tetapi tidak sebesar inokulum starter Acetobacter tropicalis InaCC B374. 
Tabel 1 Hasil Uji Aktivitas Proteolitik

\begin{tabular}{|c|c|c|c|}
\hline No. & Sampel & $\begin{array}{l}\text { Rerata Diameter Zona } \\
\text { Jernih }(\mathrm{mm}) \pm \mathrm{SD}\end{array}$ & Indeks Proteolitik \\
\hline 1 & $\begin{array}{l}\text { Starter Acetobacter tropicalis } \\
\text { InaCC B374 }\end{array}$ & $20,72 \pm 0,59$ & 2,96 \\
\hline 2 & Infusa Centella asiatica & $15,57 \pm 0,97$ & 2,22 \\
\hline 3 & $\begin{array}{l}\text { Fermentasi Centella asiatica } 0 \\
\text { jam }\end{array}$ & $16,52 \pm 0,53$ & 2,36 \\
\hline 4 & $\begin{array}{l}\text { Fermentasi Centella asiatica } \\
24 \text { jam }\end{array}$ & $16,30 \pm 1,05$ & 2,33 \\
\hline 5 & $\begin{array}{l}\text { Fermentasi Centella asiatica } \\
48 \text { jam }\end{array}$ & $14,97 \pm 0,63$ & 2,14 \\
\hline 6 & $\begin{array}{l}\text { Fermentasi Centella asiatica } \\
72 \text { jam }\end{array}$ & $15,68 \pm 0,59$ & 2,24 \\
\hline 7 & Nattokinase (Kontrol +) & $21,47 \pm 1,68$ & 3,07 \\
\hline
\end{tabular}

Jika ditinjau dari kelompok hasil fermentasi diperoleh nilai indeks proteolitik pada fermentasi 0 jam menunjukkan nilai yang lebih besar dibanding hasil fermentasi lainnya. Semakin besar nilai indeks proteolitik maka aktivitas protease dalam memecah protein kasein juga semakin besar. Diharapkan apabila terbukti memiliki aktivitas proteolitik maka akan menunjukkan aktivitas fibrinolitiknya karena enzim fibrinolitik merupakan bagian dari protease ${ }^{(7)}$.

Penelitian dilanjutkan dengan melakukan uji aktivitas fibrinolitik dengan media fibrin plate. Aktivitas fibrinolitik ditentukan dengan mengamati zona jernih yang terbentuk di sekitar sumuran seperti yang terlihat pada Gambar 2. Terbentuknya zona jernih akibat adanya proses degradasi substrat fibrin oleh enzim fibrinolitik. Untuk memudahkan pengamatan zona jernih, pada media fibrin plate ditambahkan metilen biru karena zona jernih yang terbentuk sangat tipis dan hampir tidak terlihat tanpa penambahan zat warna(25).

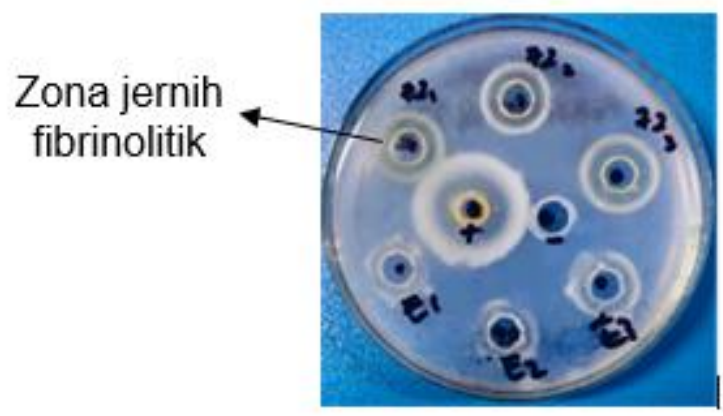

Gambar 2. Contoh hasil pengamatan zona jernih aktivitas fibrinolitik pada hasil fermentasi Centella asiatica selama 72 jam (Keterangan: $72_{123}=$ hasil fermentasi selama 72 jam replikasi 1,2,3; + = kontrol positif; - = kontrol negatif).

Pada Gambar 2 terlihat hasil yang positif karena terbentuk zona jernih disekitar sumuran sehingga dapat dikatakan sampel yang diuji menghasilkan enzim fibrinolitik. Aktivitas fibrinolitik kemudian dinyatakan dalam indeks fibrinolitik yang diperoleh dengan membandingkan diameter zona jernih pada sampel uji dengan diameter sumuran 
Tabel 2 Hasil Uji Aktivitas Enzim Fibrinolitik

\begin{tabular}{|c|c|c|c|}
\hline No. & Sampel & $\begin{array}{l}\text { Rerata Diameter Zona } \\
\text { Jernih }(\mathrm{mm}) \pm \text { SD }\end{array}$ & Indeks Fibrinolitik \\
\hline 1 & $\begin{array}{l}\text { Starter Acetobacter tropicalis } \\
\text { InaCC B374 }\end{array}$ & $20,05 \pm 0,56$ & 2,86 \\
\hline 2 & Infusa Centella asiatica & $13,62 \pm 0,51$ & 1,95 \\
\hline 3 & $\begin{array}{l}\text { Fermentasi Centella asiatica } \\
0 \text { jam }\end{array}$ & $12,42 \pm 0,51$ & 1,77 \\
\hline 4 & $\begin{array}{l}\text { Fermentasi Centella asiatica } \\
24 \text { jam }\end{array}$ & $12,52 \pm 0,64$ & 1,79 \\
\hline 5 & $\begin{array}{l}\text { Fermentasi Centella asiatica } \\
48 \text { jam }\end{array}$ & $13,12 \pm 0,85$ & 1,87 \\
\hline 6 & $\begin{array}{l}\text { Fermentasi Centella asiatica } \\
72 \text { jam }\end{array}$ & $15,50 \pm 0,62$ & 2,21 \\
\hline 7 & Nattokinase (Kontrol +) & $19,60 \pm 0,57$ & 2,90 \\
\hline
\end{tabular}

Diameter sumuran : $7,00 \mathrm{~mm}$

Dari hasil uji fibrinolitik pada Tabel 2 diatas, dapat dilihat bahwa keseluruhan sampel uji menghasilkan diameter zona jernih pada fibrin plate. Jika ditinjau dari nilai indeks fibrinolitiknya, inokulum starter Acetobacter tropicalis InaCC B374 memiliki aktivitas fibrinolitik yang paling mendekati standar nattokinase dengan aktivitas 0,98 kali lebih kecil. Sedangkan jika dilihat pada kelompok hasil fermentasi dengan variasi waktu diperoleh nilai indeks fibrinolitik tertinggi yaitu pada fermentasi selama 72 jam dengan nilai sebesar 2,21. Pada penelitian ini diperoleh nilai indeks proteolitik keseluruhan sampel yang diuji lebih besar dibandingkan dengan nilai indeks fibrinolitiknya, hal tersebut dapat dikatakan bahwa protease yang dihasilkan cenderung memiliki kemampuan untuk mendegradasi protein selain fibrin.

Setelah terbukti memiliki aktivitas proteolitik dan aktivitas fibrinolitik, maka dilanjutkan pengujian clot lysis untuk mengetahui aktivitas trombolitik sampel dan memastikan bahwa sampel uji dapat mendegradasi fibrin yang terdapat dalam darah. Darah yang digunakan pada penelitian ini merupakan darah sapi yang diambil pada vena jugularis yang merupakan salah satu pembuluh darah terbesar sehingga tidak menyakiti hewan saat diambil darahnya. Pada pengujian ini dilakukan pengamatan dan pengukuran jumlah bekuan darah yang terlisiskan setelah pemberian agen trombolitik (Gambar 3).

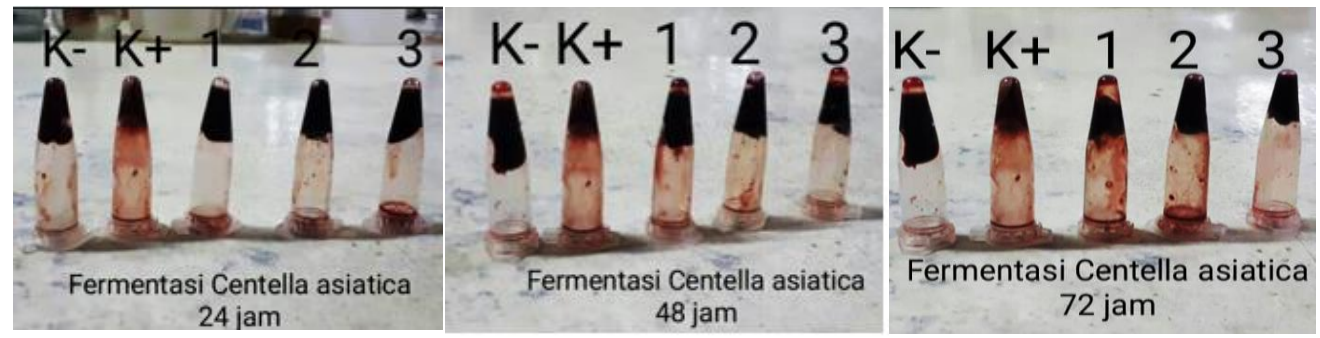

Gambar 3. Uji aktivitas trombolitik pada hasil fermentasi Centella asiatica oleh Acetobacter tropicalis InaCC B374 selama 24, 48, dan 72 jam dengan metode clot lysis (Keterangan $\mathrm{K}-$ = kontrol negatif; $\mathrm{K}+=$ kontrol positif; 1 = replikasi $1 ; 2=$ replikasi 2 dan $3=$ replikasi 3 ). 
Pada Gambar 3 terlihat bahwa terjadi proses lisis pada gumpalan darah setelah ditambahkan sampel uji. Hal tersebut dapat dikatakan bahwa sampel uji memiliki kemampuan untuk mendegradasi fibrin yang terdapat dalam darah. Besarnya gumpalan darah yang terlisis tersebut menggambarkan aktivitas trombolitik sampel yang kemudian dinyatakan dalam indeks trombolitik. Indeks trombolitik didapatkan dari hasil perbandingan antara persentase clot lysis sampel uji dengan standar nattokinase.

Tabel 3 Hasil Uji Aktivitas Trombolitik

\begin{tabular}{|c|c|c|c|}
\hline No. & Sampel & $\begin{array}{c}\text { Rerata } \\
\% \text { Clot lysis } \pm \text { SD }\end{array}$ & Indeks Trombolitik \\
\hline 1 & $\begin{array}{l}\text { Starter Acetobacter tropicalis } \\
\text { InaCC B374 }\end{array}$ & $19,38 \pm 1,13$ & 37,68 \\
\hline 2 & Infusa Centella asiatica & $19,22 \pm 1,16$ & 37,39 \\
\hline 3 & $\begin{array}{l}\text { Fermentasi Centella asiatica } 0 \\
\text { jam }\end{array}$ & $31,77 \pm 1,26$ & 61,79 \\
\hline 4 & $\begin{array}{l}\text { Fermentasi Centella asiatica } \\
24 \text { jam }\end{array}$ & $23,07 \pm 1,78$ & 44,86 \\
\hline 5 & $\begin{array}{l}\text { Fermentasi Centella asiatica } \\
48 \text { jam }\end{array}$ & $38,15 \pm 3,50$ & 74,19 \\
\hline 6 & $\begin{array}{l}\text { Fermentasi Centella asiatica } \\
72 \text { jam }\end{array}$ & $42,18 \pm 1,18$ & 82,03 \\
\hline 7 & Nattokinase (Kontrol +) & $51,42 \pm 1,84$ & 100,00 \\
\hline
\end{tabular}

Berdasarkan nilai indeks trombolitik pada Tabel 3, terdapat perbedaan aktivitas trombolitik antara waktu fermentasi satu dengan yang lainnya. Aktivitas trombolitik pada hasil fermentasi Centella asiatica selama 72 memiliki nilai indeks trombolitik yang paling besar yaitu 82,03. Hal ini menunjukkan bahwa hasil fermentasi 72 jam memiliki aktivitas untuk melisiskan bekuan darah 1,8 kali lebih besar daripada hasil fermentasi 24 jam dan 1,1 kali lebih besar daripada hasil fermentasi 48 jam. Jika dibandingkan dengan infusa Centella asiatica tanpa fermentasi aktivitas trombolitik pada hasil fermentasi 72 jam memiliki aktivitas 2,19 kali lebih besar. Berdasarkan hasil tersebut dapat dinyatakan bahwa terjadi peningkatan aktivitas trombolitik setelah dilakukan proses fermentasi Centella asiatica oleh Acetobacter tropicalis InaCC B374.

Adanya peningkatan aktivitas trombolitik karena setelah dilakukan fermentasi selama 12 jam hingga sebelum 72 jam pertumbuhan bakteri berada pada fase logaritmik dimana pada fase tersebut bakteri mengalami pertumbuhan hingga tingkat maksimum dan bakteri banyak menghasilkan molekul enzim dalam hal ini termasuk protease fibrinolitik dan enzim-enzim lain yang berperan penting pada reaksi kimia yang terlibat dalam proses fermentasi. Enzim-enzim tersebut akan menyebabkan proses biotransformasi substrat kompleks yang ada pada media fermentasi menjadi komponen bioaktif yang lebih spesifik sehingga efek terapetiknya dapat meningkat ${ }^{(16,29)}$. Selain itu, saat memasuki fermentasi selama 72 jam bakteri mulai memasuki fase stationer dimana pada fase tersebut mulai dihasilkan metabolit sekunder oleh bakteri sehingga senyawa yang berperan pada aktivitas trombolitik tidak hanya protease fibrinolitik tetapi 
juga metabolit sekunder yang dihasilkan saat fase stationer(30).

Berdasarkan hasil perhitungan indeks trombolitik (Tabel 3) dapat dilihat bahwa fermentasi 0 jam ke 24 jam mengalami penurunan, hal ini dapat disebabkan oleh adanya perubahan kondisi lingkungan setelah dilakukan proses inokulasi bakteri dari media starter ke media fermentasi, sehingga bakteri membutuhkan proses adaptasi dan hal tersebut juga dapat menyebabkan jumlah sel bakteri yang aktif mengalami penurunan. Pada waktu fermentasi 48 jam dan 72 jam terjadi peningkatan hasil indeks trombolitik. Hal ini disebabkan sel bakteri telah berupaya mengembalikan pola metabolismenya, sehingga bakteri sudah dapat beradaptasi dan aktivitasnya meningkat kembali secara signifikan(31).

Jika ditinjau dari data hasil uji statistik, pada pengujian one way anova diperoleh nilai $\mathrm{F}$ hitung 132,061 lebih besar daripada $F$ tabel yaitu 2,85. Hal tersebut menunjukkan Ho ditolak sehingga dapat disimpulkan terdapat perbedaan yang bermakna antar kelompok uji. Untuk mengetahui kelompok mana yang memberikan perbedaan yang bermakna, pengujian dilanjutkan dengan Post Hoc Multiple Comparison. Pada uji tersebut, dilakukan dua macam pengujian yaitu uji LSD dan uji Duncan. Pada uji LSD didapatkan nilai Mean Difference antara kelompok fermentasi 72 jam dan infusa Centella asiatica memiliki nilai yang paling besar yaitu 22,9533 dan pada uji Duncan diperoleh nilai Homogenous Subsets pada kelompok fermentasi selama 72 jam menunjukkan hasil yang paling besar dibandingkan dengan kelompok uji lainnya yaitu dengan nilai 42,1767. Dari hasil tersebut dapat dikatakan bahwa proses fermentasi pada daun Centella asiatica oleh Acetobacter tropicalis InaCC B374 selama 72 jam terbukti dapat meningkatkan aktivitas trombolitik secara signifikan.

\section{Kesimpulan}

Terjadi peningkatan aktivitas trombolitik yang signifikan setelah dilakukan proses fermentasi pada daun Centella asiatica oleh Acetobacter tropicalis InaCC B374 jika dibandingkan dengan infusa Centella asiatica tanpa fermentasi. Aktivitas trombolitik maksimum tercapai setelah dilakukan proses fermentasi selama 72 jam.

\section{Ucapan Terimakasih}

Artikel ini telah dipaparkan pada Pertemuan IImiah Tahunan Ikatan Apoteker Indonesia tahun 2021.

\section{Daftar Pustaka}

1. Collen D, Lijnen HR. Thrombolytic agents. Thromb Haemost. 2005;93(4):627-30.

2. Akhtar T, Hoq MM, Mazid MA. Bacterial proteases as thrombolytics and fibrinolytics. Dhaka Univ J Pharm Sci. 2017;16(2):255-69. 
3. Stephani L, Tjandrawinata RR, Afifah DN, Lim Y, Ismaya WT, Suhartono MT, et al. Food Origin Fibrinolytic Enzyme With Multiple Actions. Hayati J Biosci. 2017;24(3):124-30.

4. Kotb E. Activity assessment of microbial fibrinolytic enzymes. Appl Microbiol Biotechnol. 2013;97(15):6647-65.

5. Afifah DN, Sulchan M, Syah D, Yanti, Suhartono MT, Kim JH. Purification and Characterization of a Fibrinolytic Enzyme from Bacillus pumilus 2.g Isolated from Gembus, an Indonesian Fermented Food. Prev Nutr Food Sci. 2014;19(3):213-9.

6. Raju EVN, Divakar G. An Overview on microbial fibrinolytic proteases. Int J Pharm Sci Res. 2014;5(3):643-56.

7. Kotb E. Fibrinolytic Bacterial Enzymes with Thrombolytic Activity. SpringerBriefs in Microbiology. 2012. 1-69 p.

8. Newell P, Chaston J, Wang $Y$, Winans N, Sannino D, Wong A, et al. In vivo function and comparative genomic analyses of the Drosophila gut microbiota identify candidate symbiosis factors. Front Microbiol. 2014;5:1-15.

9. Park J, Yoon S, Kim S, Lee B, Cheong H. Characterization and fibrinolytic activity of Acetobacter sp. FP1 isolated from fermented pine needle extract. J Microbiol Biotechnol. 2012;22(2):215-9.

10. Bajaj BK, Singh S, Khullar M, Singh K, Bhardwaj S. Optimization of fibrinolytic protease production from Bacillus subtilis I-2 using agro-residues. Brazilian Arch Biol Technol. 2014;57(5):653-62.

11. Zahara K. Clinical and therapeutic benefits of Centella asiatica. Pure Appl Biol. 2014;3(4):152-9

12. Rishikesh, Ghosh DR, Rahman MM. Thrombolytic Activity of Centella asiatica Leaves. Int J Pharm. 2013;3(2):308-11.

13. Forte R, Cennamo G, Finelli ML, Bonavolonta P, Crecchio G De, Greco GM. Combination of Flavonoids with Centella asiatica and Melilotus for Diabetic Cystoid Macular Edema Without Macular Thickening. J Ocul Pharmacol Ther. 2011;27(2):109-13.

14. Evangelista JH, Vera MJ De, Garcia RS, Joven MG, Solidum JN. Preliminary Assessment of In vitro Anticoagulant Activity vs. Heparin 1,000I.U. and Cytotoxicity of Selected Philippine Medicinal Plants. Int J Chem Environ Eng Prelim. 2012;3(6):372-6.

15. Singh R. Microbial Biotransformation: A Process for Chemical Alterations. J Bacteriol Mycol. 2017;4(2):47-51.

16. Hussain A, Bose S, Wang JH, Yadav MK, Mahajan GB, Kim H. Fermentation, a feasible strategy for enhancing bioactivity of herbal medicines. Food Res Int. 2016;81:1-16. 
16. Hussain A, Bose S, Wang JH, Yadav MK, Mahajan GB, Kim H. Fermentation, a feasible strategy for enhancing bioactivity of herbal medicines. Food Res Int. 2016;81:1-16.

17. Mertz C, Ranovona Z, Dhuique-Mayer C, Servent A, Dornier M, Danthu P, et al. The nutrient content of two folia morphotypes of Centella asiatica $(\mathrm{L})$ grown in Madagascar. African J Food Agric Nutr Dev. 2019;19(3):14654-73.

18. Adamczyk B, Smolander A, Kitunen V, Godlewski M. Proteins as nitrogen source for plants: A short story about exudation of proteases by plant roots. Plant Signal Behav. 2010;5(7):817-9.

19. Leyn SA, Maezato Y, Romine MF, Rodionov DA. Genomic reconstruction of carbohydrate utilization capacities in microbial-mat derived consortia. Front Microbiol. 2017;8:1-17.

20. Rohmah MK, Fickri DZ, Kasifa W, Wahyuni KI. Uji Aktivitas Fibrinolisis Infusa Alkaloid Total Rimpang Lengkuas Merah (Alpinia purpurata (Vielli) K.Schum) Secara In Vitro. J Pharm Care Anwar Med. 2019;2(1):1-11.

21. Salamah A, Srihardyastutie A, Prasetyawan S, Safitri A. Influence of mixed cultures of Saccharomyces cerevisiae and Acetobacter aceti for hydrolysis of tannins in the cabbage fermentation (Brassica oleracea L.var.capitata). IOP Conf Ser Mater Sci Eng. 2019;546(6):1-7.

22. Borhan MZ, Ahmad R, Rusop M, Abdullah S. Green Extraction: Enhanced Extraction Yield of Asiatic Acid from Centellaasiatica (L.) Nanopowders . J Appl Chem. 2013;2013:1-7.

23. Madhusudhan NC, Neeraja P, Devi P. Comparative analysis of active constituents in Centella asiatica varieties (Majjaposhak and Subhodak). Int J Pharm Phytopharm Res. 2014;4(2):105-8.

24. Rosada KK. Enhanced acetic acid production from manalagi apple (Malus sylvestris mill) by mixed cultures of Saccharomyces cerevisiae and Acetobacter aceti in submerged fermentation. J Phys Conf Ser. 2018;1013(1):1-7.

25. Poernomo AT, Isnaeni, Purwanto. Aktivitas Invitro Enzim Fibrinolitik Infusa Tempe Hasil Fermentasi Rhizopus oligosporus ATCC 6010 Pada Substrat Kedelai Hitam. Berk IIm Kim Farm. 2014;4(2):18-24.

26. Ashipala OK, He Q. Optimization of fibrinolytic enzyme production by Bacillus subtilis DC-2 in aqueous two-phase system (poly-ethylene glycol 4000 and sodium sulfate). Bioresour Technol. 2008;99(10):4112-9.

27. Prasad S, Kashyap RS, Deopujari JY, Purohit HJ, Taori GM, Daginawala HF. Development of an in vitro model to study clot lysis activity of thrombolytic drugs. Thromb J. 2006;4(14):9-12. 
28. Ratnasooriya WD, Fernando TSP, Madubashini PP. In vitro thrombolytic activity of Sri Lankan black tea, Camellia sinensis (L.) O. Kuntze. J Natl Sci Found Sri Lanka. 2008;36(2):179-81.

29. Wang B, Pu Y, Gerken HG, Xie Y, Lin L, Chen H, et al. Production of D-Glyceric Acid by a Two-step Culture Strategy Based on Whole-cell Biocatalysis of Acetobacter tropicalis. Chem Biochem Eng Q. 2018;32(1):135-40.

30. Feng R, Chen L, Chen K. Fermentation trip: amazing microbes , amazing metabolisms. Ann Microbiol. 2018;68:717-29.

31. Giraffa G. Studying the dynamics of microbial populations during food fermentation. FEMS Microbiol Rev. 2004;28:251-60. 